\title{
Effect of Insurance Business on Economic Growth and Development in Nigeria
}

\author{
Michael Chukwunaekwu Nwafor \\ Department of Accounting and Finance \\ Godfrey Okoye University, Enugu \\ michaelandstephens@yahoo.com
}

\section{Abstract}

This research work explored insurance business in Nigeria and its effect on economic growth and development. A data span from 2007 to 2016 was obtained and analyzed using Ordinary Least Squares (OLS) regression method. Two hypotheses were subjected under tests and results showed that insurance business in Nigeria has significant impact on economic growth in Nigeria and that insurance business has significant impact on unemployment rate in Nigeria. It was recommended however that National Insurance Commission (NAICOM) should ensure proper monitoring of payment of claims by insurance companies so as to ensure transparency, avoid extortion and incorporate prudency which will in turn elicit public confidence in the services rendered by the insurance companies and hence, promote economic growth.

Keywords: Insurance Premium; NAICOM; Insurance Claim; Risk

Though insurance is of primeval significance in domestic and international economies, the role of insurance business in the growth and development of an economy remain difficult to assess even though it has been recognized since the 1960s by some authors. Insurance is so vital in the trade and development matrix that, UNCTAD (1964) at its initial session, indorsed that a sound national insurance and re-insurance market is a crucial characteristic of economic growth.

The Insurance sector in Nigeria, like other insurance industries all over the world has grown in quantitative importance as part of the spread-out advancement of financial institutions, its qualitative importance has also grown as a result of increased risks and uncertainties in the country. Theeconomic importance of the insurance sector has been on the positives as part of the liberalization of financial systems, globalization and conglomeration of financial markets. The total premium of the insurance industry hit its highest in 2016 with a total insurance premium of \$380billion(Onuoha, 2017). This however can be attributed to increased need to manage risk and disaster among firms in Nigeria considering the socio-political situation of the country.

The insurance industry in Nigeria is a vast industry that gives great security to the treasure of people and entities. It is one of the pillars of Nigerian financial industry.

Nigeria is gearing itself gradually towards economic sustainability and a growing insurance industry aids growth and development in the economy. Savings and investment will be encouraged as well as job creation and increased in financial assets and capital markets. Over the past decade, the insurance industry of Nigeria has grown steadily and this can be shown in the total premiums which have gone from about $\$ 101$ billion in 2007 to $\$ 380$ billion in 2016 representing almost upsurge of almost $300 \%$ within a space of 10 years. Given this, the Nigerian insurance industry is expected to increase up to 1 trillion by 2024 .

Even though Nigeria has shown positive signs of development in insurance activity, there is still room for more growth when compared to other emerging markets. Hence the need for this research work as some of the policy recommendations, if adhered to will aid raise a financial giant out of 
the Nigerian insurance sector of the economy.

\section{Research Objectives}

1. To ascertain the extent to which insurance business influences economic growth in Nigeria

2. To examine if the insurance industry has any significant impact on the rate of unemployment in Nigeria.

\section{Literature Review}

\section{Brief history of Insurance in Nigerian}

The arrival of British trading companies in Nigeria heralded the birth of insurance companies in Nigeria. The need to deal with local trade risks by managers of those British companies was the bed rock upon which development of the Nigerian insurance sector was anchored. The first insurance firm in Nigeria was the Royal Exchange Assurance Agency which was established in the year 1918. Other insurance companies in Nigeria was: BEWAC's Legal and General Assurance; Patterson Zochonis (PZ) Liverpool and Law Union and Rock. The initial years of insurance sector in Nigeria witnessed slow growth between 1920s to 1940s as a consequence of the second world war which affected both Nigerian and United Kingdom insurance sectors (Jegede, 2005). The African Insurance Company Limited established in 1958 was the first insurance company indigenous to Nigeria. By the time Nigeria gained her independence in the year 1960, there were about twenty-five insurance companies out of which four where owned by Nigerians (Jegede, 2005). Regulation of Nigeria insurance industry has become considerably strengthened in the last two decades (Ezekiel, 2005) with the first major step seen in the J.C Obande commission report of 1961 titled a milestone in the history of insurance in Nigeria whose release led to the creation of the Nigerian Department of Insurance as a fragment of the Federal Ministry of Trade although the department was later transferred to the ministry of finance. The Insurance Companies Act of 1961 made it essential for insurance companies to be grouped into various classes for registration and also the creation of office of the registrar of insurance whose main function was to manage insurance practice in the country was effected according to provisions of the act. In 1997, the National Insurance Commission charged with the responsibility of overseeing and organizing insurance in Nigeria was established. Furthermore, an Insurance Special Supervisory Fund was established in 1989, which made it obligatory for insurance companies to give in $1 \%$ of their gross incomes to the fund which strengthened the Insurance Supervisory Board. Insurance in Nigeria are categorized into the following areas namely Property, casualty, life assurance and marine/aviation whichever disaster that could occur that insurance company needs to address falls under any of this category. One of the significant aftermath of the consolidation and recapitalization in the Nigerian insurance sector was the recertification of forty-nine companies as against over hundred companies that were in existence in 2005 (Ozumba, 2013)

\section{Overview of Insurance in Nigeria}

The Nigerian insurance sector can be described as being irrepressible because in the face of high level of unconcern for insurance shown by a large number of the Nigerian populace which clearly is either determined by cultural or religious affiliations, the industry recorded a compounded annual growth rate (CAGR) of 10.2\% in gross premium Income (GPI) in 2012 as a result of the implementation of mandatory insurance policies, especially in the group life and motor insurance business lines by the insurance companies. Due to the falling oil prices in 2014, the growth of sector suffered a setback as contributions to the non-life sector of insurance from the oil and gas 
industry reduced. The enactment of the pension reform act of Nigeria in the same 2014 which allows pension funds administration (PFAs) transfer funds for annuity purpose to insurance companies made the life insurance sector in Nigeria to record an $84 \%$ growth in life premiums in 2015. The high level of inflation in Nigerian economy is also affecting the growth of the insurance sector as regards to the Industry's operating costs which in turn reduces profits. In 2016, about $28 \%$ of the Industry's GPI was paid out as underwriting expenses (including acquisition and maintenance costs) and also because of recession faced by the Nigerian economy, the Nigerian Insurance Industry continued to record increased claim payment which is usual in times of recession; net claims paid by operators amounted to an estimated $\$ 100$ billion ( $\$ 327.9$ million at \$305 per dollar), a 19\% growth over the preceding year which means that the industry recorded an average loss ratio of $43.7 \%$. The rapid expansion being experienced by the Nigerian economy is exposing businesses to new risks and as such, businesses and people need to be insured in preparation for the event of unexpected losses. By so doing the economy is able to rebuild and recover from losses quickly. A clear lag is seen when the level of penetration of Nigerian insurance sector is compared with that obtainable in countries like Kenya and South which boast of insurance penetrations of $2.9 \%$ and $14 \%$ respectively.

\section{Empirical Overview}

Oke (2012), in his work reviewed the short and long-run connections between economic and insurance sector growth in the Nigerian economy. The study adopted the fixed-effect model, where significant data within the period of 1985 and 2009 were gathered and analyzed with the use of co-integration analysis adopting Gross domestic product (GDP) as a proxy for the level of economic growth, while numbers of insurance companies (NIC), premium of life-insurance (PLI), premium of non-life insurance (NLP), total insurance investment (TII), and inflation rate (INF) were used in assessing insurance sector growth in Nigeria. The outcomeof the analysis showed that insurance sector growth and development positively and significantly affects economic growth in Nigeria. The result of the Granger causality test also employed in analyzing the work also revealed that the level of influence the insurance sector growth had on economic growth was limited and not direct because of some traditional, attitudinal qualities and principles in the country. The researcher suggested that government should create a good environment for insurance undertakings in Nigeria and that the insurance companies in addition to engaging in insurance undertakings that is both environment and customer friendly should also come up with policies that can accommodate every part of the Nigerian economy.

Arena (2008) undertook an empirical study and fundamental relationship among insurance market action and economic growth on 56 countries (comprising of developing and developed countries) within the period 1976to 2004. The researcher used insurance premiums as a representation of total life and non-life insurance activities separately and also applied as an estimation method, the generalized method of moment for dynamic models of panel data. The result of the analysis showed a positive and substantial effect of total, life and non-life insurance market activity on economic growth. The researcher tried to show the possibility of nonlinear effect of life and non-life insurance variables on economic growth but the results gotten from his analysis did not show the nonlinearity in the relationship.

Haise and Sumeg (2008) in their work indicated that there is a positive impact of life insurance on GDP growth in some EUcountries namely Switzerland, Norway and Iceland, while non-life insurance has a greater influence in Central and Eastern Europe. This they achieved by applying a cross country paneldata analysis from 29 European countries within the period 1992 to 2005 where 
the insurance variable is measured by premium income and total net investment of insurance companies. They further split the premium income is into life and non-life premium income and the researchers also made use of ordinary least squares (OLS) or unbalanced panel with country and time-fixed effects as estimation method for the work.

Marijuana, Sandra and Lime(2009) in the empirical study they carried out to examine the association between growth in both the insurance and economic sectors in 10 transition European Union member countries in the period from 1992 to 2007 using different insurance variables like life, non-life and total insurance and other control variables like education, openness, inflation, investment, bank credit, stock capitalization found out that the insurance sector advancement positively and significantly affects economic growth.

The work of Akinlo and Aparisile (2014) examined the relationship between insurance and economic growth in sub-Saharan Africa within the period 1986-2011. After the estimation of the dynamic panel-data utilizing Pooled OLS, Fixed Effect Model and Generalized Method of Moment Panel Model, the result obtained by the researchers showed that insurance has positive and significance impact on economic growth in sub Saharan Africa. The result further shows that premium contributes significantly to economic growth in sub-Saharan Africa which implies that a well-structured insurance sector is essential for economic development, as it offers long-term investments for economic growth and at the same time consolidating risk-taking capabilities. The outcome of the panel data model analysis also showed that human capita has positive significant influence on economic growth and that ingenuousness and interest rate have negative and statistical significance on economic growth.

Kjosevski and Stopanaka (2011) examined the impact of insurance on economic growth in the Republic of Macedonia by applying multiple regression and control on other relevant growth determinants using data collated for the period 1995-2010 utilising ordinary least squares, analysis of variability to ascertain the effect of each variable. Furthermore, the study applied three insurance variables in the data analysis, namely: life insurance, non-life insurance and total insurance penetration. The result of the analysis showed that insurance sector development positively and significantly affects economic growth while life insurance adversely affects economic growth.

Oyedotun and Babajide (2015) examined extensively the role of insurance sector in alleviating unexpected and overwhelming incidences thereby encouraging economic growth in Nigeria. This role they opined cannot be over stressed though according to them that no agreement has been established on the influence of insurance development on economic growth. Data obtained from secondary sources were regressed using ordinary least square at 95\% significant level which led the researchers to the discovery that there is relationship between insurance business and economic growth within the period of study in Nigeria

Yinusa and Akinlo (2013) analyzed concurrently the long and short run relationship between insurance development andeconomic growth in Nigeria over the period 1986 to 2010. The study employed error correction model (ECM) in the analysis of data. The result of their analysis shows that insurance development co-integrated with economic growth in Nigeria in other words, that there exists a long run relationship between insurance development and economic growth in Nigeria. The result of their analysis also show that physical capital and interest rate both at present and one protected value has significant positive effect on economic growth in Nigeria while physical capital and inflation has adverse long run relationship with economic growth. Generally, the result of their findings show that the insurance sector has great contribution to economic growth in Nigeria. 
Epetimehin and Obafemi (2011) carried out an empirical study which covers the period from 2003 to 2007 using the insurance industry to show that inflation is creating a serious problem for the rapid growth of the insurance sector and consequently the Nigerian economy. Their study focused on the Life Insurance product (an aspect that provides savings plans and in direct competition with other investment assets from the commercial banks, savings associations, mutual funds, real estate, and also whole life policies) of the insurance Industry which provides a unique product of Insurance Protection and the effect on the product over the years. The study looked at types of life insurance products and the effect inflation has on the demand and cost of the policies and also the historical performance of the insurance industry within the period under review. The researchers recommended that Insurance Industries in Nigeria should design cash surrender value insuranceproducts which will provide at least areasonable partial hedge against inflation to cushion the effect of inflation on the industry.

Umoren \& Emem (2016) investigated the relative contributions of the insurance industry to the growth of theNigerian economy. They employed a multiple linear regression method to test the researchhypothesis. Their findings revealed that insurance sectorgrowth has contributed significantly to the economic growth in Nigeria within the period under study. Premium income of insurance industry had a positive influence on GDP but was statistically insignificantly in explaining the changesin the contribution of insurance industry to the economic growth in Nigeria. Their findings also showed that claims expenditure has a negative influence on GDP growth in Nigeria. They recommended thus that Claims manager can be trained in claims reporting process like,minimization of losses, investigation, verification of claims, loss evaluation and assessing the extent of the damage prior to any repair or replacement. This according to them will help reduce the frequency of claims reports and boost premium incomefor economic development and growth. Olayungbo \& Akinlo (2016) examined the dynamic interactions between insurance andeconomic growth in eight African countries for the period of 1970 to 2013. A BayesianTime VaryingParameterVectorAutoregression(TVP-VAR)model with stochastic volatility was used to analyze the short-runand the long-run among the variablesof interest.Using insurancepenetrationasa measureof insurance to economic growth, they found positiverelationshipforEgypt,while short-run negativeand long-run positiveeffectsarefoundforKenya,Mauritius,and South Africa. On the other hand,negativeeffects were foundforAlgeria,Nigeria,Tunisia, and Zimbabwe.Implementationof sound financial reformsandwideinsurancecoverage is recommended forinsurancedevelopment in the selectedAfricancountries.

Oluoma (2017) examined the Impact of Insurance Market Activity on Economic Growth in Nigeriaby adopting the ex-post facto research design and annualized cross sectional data for 26-year period 1987 to 2012 collated from the Nigerian Central Bank Statistical Bulletin, National Insurance Commission and Nigerian Insurers Association. The researcher proposed four hypotheses which were tested using the Ordinary Least Square (OLS) regression model. Descriptive statistics and graphs were also used by the researcher to complement the result gotten from the regression analysis. The findings of the researcher from the study indicated that while life insurance penetration and insurance density had positive and significant impact on economic growth in Nigeria, both total insurance penetration and non-life insurance penetration had positive but insignificant impact on economic growth in Nigeria under the period of this study. The researcher recommended that government policies towards insurance sector should focus more on attracting rural dwellers into the insurance bracket as this will boost savings thereby ensuring availability of funds for real sector investment. 
Olayungbo(2015) studied the effects of lifeand non-life insurance on economic growth in Nigeria from the period 1976 to 2013. He adopted the Autoregressive Distributed lags (ARDL) given the different order of integration of the variablesof interest to analyse the data he collated. The bound test result of the analyses showed that a long run relationship exists among economic life,non-life insurance and economic growth in Nigeria over theperiod of study. The long run and the short run dynamics of the result of his analysis further confirms the positive and significant contribution of lifeand non-life insurance on economic growth in Nigeria. The researcher concludes that life and non-life insurance acts assupplements to economic growth in Nigeria rather replacements.

\section{Research Methodology}

Ex post-facto research was employed which aims at determining or measuring the relationship between one variable and another or the impact of one variable on another.

The nature of data for the analysis of this study is secondary accessed fromthe Central Bank of Nigeria Statistical Bulletin, 2016; Onuoha, 2017; Nwoji, 2016; World Bank Database. A regression model has been employed, the essence of regression is to use a mathematical equation to express the nature of the relationship existing between variables and ultimately to use this equation to predict the of value one variable given a specific value of the other variable (Ugbam, 2001).

The following is a simple regression model

$\mathrm{Y}=\mathrm{b}_{0}+\mathrm{b}_{1} \mathrm{X}+\mu$.

Where

$\mathrm{Y}=$ the variable we are trying to predict; $\mathrm{b}_{0}=$ the intercept; $\mathrm{b}_{1}=$ the slope; $\mathrm{X}=$ the variable we are using to predict $Y ; \mu=$ the error term.

The intercept $\left(b_{0}\right)$ is the value of the dependent variable when the independent variable is equal to zero while the slope of the regression line $\left(\mathrm{b}_{1}\right)$ represents the rate of change in $\mathrm{Y}$ as $\mathrm{X}$ changes. Because $\mathrm{Y}$ is dependent on $\mathrm{X}$, the slope describes the predicted values of $\mathrm{Y}$ given $\mathrm{X}$.

The above model can thus be applied in this study as:

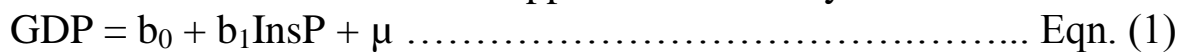

Unempl $=b_{0}+b_{1} \operatorname{Ins} P+\mu \ldots \ldots \ldots \ldots \ldots \ldots \ldots \ldots \ldots \ldots \ldots$. Eqn. (2)

Where:

GDP - percentage change inGross Domestic Product

InsP - Insurance Premium

Unempl - Unemployment Rate

\section{Techniques of Data Analysis}

Ordinary Least Squares method is employed using Statistical Package for Social Sciences (SPSS) version 22.0. The aim of using this method is to minimize the error in our prediction of the dependent variable, and by minimizing the residuals, error will be minimized. By using the "squares" the researcher is preventing the problem of signs thus giving positive and negative prediction errors same importance. 
DOI : $\underline{\text { https://dx.doi.org/10.26808/rs.rm.i6v7.04 }}$

International Journal of Research in Management

ISSN 2249-5908

Available online on http://www.rspublication.com/ijrm/ijrm_index.htm

Issue 7, Vol. 6 (October-November 2017)

Data Presentation and Analysis

Decision Rule: Reject $\mathrm{H}_{0}$ if p-value $\leq .05$, otherwise do not reject $\mathrm{H}_{0}$

Table 1 Necessary Variables for Analysis

\begin{tabular}{|c|c|c|c|}
\hline Year & InsP & GDP & Unempl \\
\hline 2007 & 101 & 7.32 & 7.147 \\
\hline 2008 & 150 & 7.2 & 7.192 \\
\hline 2009 & 180 & 8.35 & 7.238 \\
\hline 2010 & 186 & 9.54 & 7.286 \\
\hline 2011 & 218 & 5.31 & 7.334 \\
\hline 2012 & 252 & 4.21 & 7.6 \\
\hline 2013 & 268 & 5.49 & 7.1 \\
\hline 2014 & 294 & 6.22 & 4.8 \\
\hline 2015 & 350 & 2.79 & 4.275 \\
\hline 2016 & 380 & -1.51 & 5.005 \\
\hline
\end{tabular}

Sources: CBN Statistical Bulletin, 2016; Onuoha, 2017; Nwoji, 2016; World Bank Database

Model Summary

\begin{tabular}{|c|c|c|}
\hline \multirow[t]{4}{*}{ Equation 1} & Multiple R & .820 \\
\hline & R Square & 672 \\
\hline & Adjusted R Square & .631 \\
\hline & Std. Error of the Estimate & 1.915 \\
\hline
\end{tabular}

ANOVA

\begin{tabular}{|cc|c|c|c|c|c|}
\hline & & & & & \\
& & Sum of Squares & df & Mean Square & F & Sig. \\
\hline Equation 1 & Regression & 60.025 & 1 & 60.025 & 16.376 & .004 \\
& Residual & 29.324 & 8 & 3.665 & & \\
& Total & 89.349 & 9 & & & \\
\hline
\end{tabular}

Coefficients

\begin{tabular}{|cc|c|c|c|c|c|}
\hline & & \multicolumn{2}{|c|}{ Unstandardized Coefficients } & & & \\
& & $\mathrm{B}$ & Std. Error & Beta & & \multicolumn{1}{c|}{ Sig. } \\
\hline \multirow{2}{*}{ Equation 1 } & (Constant) & 12.455 & 1.824 & & 6.828 & .000 \\
& InsP & -.029 & .007 & -.820 & -4.047 & .004 \\
\hline
\end{tabular}

The $\mathrm{R}$ of .820 above shows that there is a strong positive relationship between the explanatory variable (InsP) and the dependent variable (GDP). The R2 of .672 shows that about $67.2 \%$ of the variation in GDP growth rate can be explained by Insurance Premium. The Anova table shows that the model fit is statistically significant (p-value $.004<.05)$, thus valid for prediction. The intercept 12.455 shows the value of GDP when InsP is constant. The slope of -.029 shows that at every 
percentage increase in InsP, GDP will decrease by $2.9 \%$. After replacing the intercept, the slope and the standard error from the above regression output, the model will look this way, GDP = $12.455-.029 \operatorname{InsP}+1.915$.

\section{Decision}

$H_{0}$ : Insurance business in Nigeria has no significant impact on economic growth in Nigeria

The P-value on which basis the above hypothesis can be rejected or not is .004. Since the p-value < .05 , the null hypothesis is rejected therefore and alternatively confirm that insurance business in Nigeria has significant impact on economic growth in Nigeria.

\begin{tabular}{|c|c|c|}
\hline \multicolumn{3}{|c|}{ Model Summary } \\
\hline Equation 1 & Multiple R & .771 \\
\hline & R Square & .594 \\
\hline & Adjusted R Square & .543 \\
\hline & Std. Error of the Estimate & .855 \\
\hline
\end{tabular}

\begin{tabular}{|cc|c|c|c|c|c|}
\hline & & & & & \\
& & Sum of Squares & Df & Mean Square & F & Sig. \\
\hline \multirow{2}{*}{ Equation 1 } & Regression & 8.550 & 1 & 8.550 & 11.690 & .009 \\
& Residual & 5.851 & 8 & .731 & & \\
& Total & 14.401 & 9 & & & \\
\hline
\end{tabular}

Coefficients

\begin{tabular}{|cc|c|c|c|c|c|}
\hline \multirow{2}{*}{} & \multicolumn{2}{|c|}{ Unstandardized Coefficients } & & \multirow{2}{*}{} & \\
\cline { 3 - 7 } & & $\mathrm{B}$ & Std. Error & Beta & $\mathrm{t}$ & $\mathrm{S}$ \\
\hline \multirow{2}{*}{ Equation 1 } & (Constant) & 9.128 & .816 & & 11.193 & .000 \\
& InsP & -.011 & .003 & -.771 & -3.419 & .009 \\
\hline
\end{tabular}

The $\mathrm{R}$ of .771 above shows that there is a strong positive relationship between the explanatory variable (InsP) and the dependent variable (Unempl) as the $\mathrm{R}$ is very close to 1 . The $\mathrm{R}^{2}$ of .594 shows that about $59.4 \%$ of the variation in Unempl can be explained by InsP. The Anova table shows that the model fit is statistically significant ( $p$-value $.009<.05$ ). The intercept 9.128 shows the value of Unempl when InsP is constant. The slope of -.011 shows that at every percentage increase in Insurance Premium, unemployment rate will decrease by 1.1 percent. After replacing the intercept, the slope and the standard error from the above regression output, the model will take this look, Unempl $=9.128-0.011$ Unempl +0.855

\section{Decision}

$H_{0}$ : Insurancebusiness has no significant impact on unemployment rate in Nigeria

The P-value on which basis the above hypothesis can be rejected or not is .009 . Since the p-value < .05 , the null hypothesis is therefore rejected and alternatively conclude that insurance has 
significant impact on unemployment rate in Nigeria.

\section{Findings/Discussion}

Having subjected the hypotheses under empirical tests, it was found that

1. Insurance business in Nigeria has significant impact on economic growth in Nigeria.

The result of this finding is quite different from recent authors who explored the relationship between insurance business and economic growth in Nigeria. This slight difference in results could be as a result of the measuring indices employed by the varying authors. While authors like Umoren \& Emem (2016)and Oluoma (2017)employed raw GDP amount as indicesfor economic growth, this research work used percentage change in GDP to measure economic growth as it happens to be the most suitable in measuring economic growth.

2. Insurance business has significant impact on unemployment rate in Nigeria.

This finding does not only signify that insurance has some impact on unemployment rate in Nigeria, it further specified the direction of the effect. The slope of -0.11 shows that there exists an inverse relationship between insurance business and unemployment in Nigeria - unemployment rate in Nigeria reduces by $1.1 \%$ at every percentage increase in insurance activity.

\section{Conclusion/Recommendation}

This study has succeeded in establishing that Insurance Business in Nigeria has significant effect on economic growth and development. This however is well supported by the Slopes of the regression models which showed that the effect is positive. This suggests that establishing a viable insurance industry in thecountry would immensely boost economic growth in Nigeria.

In view of the findings, the following recommendations are made however

1. The insurance industries in Nigeria should start advancing steps to introduce new insurance products in the growing mortgage and housing sector in Nigeria.

2. Insurance companies in Nigeria should consider repackaging and rebranding of insurance products in order to reach small scale businesses, middle and low income households in Nigeria.

3. National InsuranceCommission (NAICOM)should ensure proper monitoring of payment of claims by insurance companiesso as to ensure transparency, avoid extortion and incorporate prudency which willin turn elicit public confidence in the services rendered by the insurancecompanies and hence, promote economic growth.

\section{References}

Akinlo, T., \& Apanisile, O. T. (2014). Relationship between Insurance and Economic Growth in Sub-Saharan African: A Panel Data Analysis . Modern Economy, 120-127.

Arena, M. (2008). Does insurance market promote Economic Growth? A cross-country Study for Industrialized And developing countries. Journal of Risk Insurance, 921-946.

Epetimehin, F. M., \& Obafemi, F. (2011). The Empirical Analysis of the Impact of Inflation on the Nigeria Insurance Industry. Journal of Emerging Trends in Economics and Management Sciences (JETEMS), 453-460.

Ezekiel, O. C. (2005). The Nigerian Insurance Market In The Context Of the Insurance Act 2003. Lagos: Nigeria Insurance Association.

Haiseg, P., \& Sumeg, K. (2008). The relationship between Insurance and Economic Growth in Europe. A Theoretical and empirical analysis. Emperica, 405-431. 
Jegede, M. I. (2005). A Comprehensive Analysis of the Insurance Act 2003 and Its Implications on the Insurance Business Environment Issues In Merger and Acquisition for the Insurance Industry. Lagos: Nigeria Insurance Association.

Kjosevski, J., \& Banka , S. (2011). Impact of insurance on Economic Growth: The case of Republic of Macedonia. European Journal of Business and Economics, 34-39.

Marijuana, C., Sandra, L., \& Lime, P. (2009). Insurance Sector development and Economic growth in Transition countries. International Research Journal of Financial Economics.

Nwoji, E. (2016, July 4). Insurance Industry's Total Premium Hits N350bn . Retrieved from This Day Live:

https://www.thisdaylive.com/index.php/2016/07/04/insurance-industrys-total-premium-hi ts-n350bn/

Oke, M. O. (2012). Insurance sector development and economic growth in Nigeria. African Journal of Business Management, 7016-7023.

Olayungbo, D. (2015). Effects of Life and Non-Life Insurance on Economic Growth in Nigeria: An Autoregressive Distributed Lag (ARDL) Approach. Global Journal of Management and Business Research: Finance, 32-40.

Olayungbo, D. O., \& Akinlo, A. E. (2016). Insurance penetration and economic growth in Africa: Dynamic effects analysis using Bayesian TVP-VAR approach. Cogent Economics \& Finance, 1-19.

Oluoma, R. O. (2017). Impact of Insurance Market Activity on Economic Growth in Nigeria. Dissertation.

Onuoha, R. (2017, July 3). Insurance gross premium income rises $22 \%$ to N380bn. Retrieved from Vanguard News: https://www.vanguardngr.com/2017/07/insurance-gross-premium-income-rises-22-n380b $\mathrm{n} /$

Oyedotun, T. M., \& Babajide, D. A. (2015). Nexus between Economic Growth and Insurance Business in Nigeria. Research Journal of Finance and Accounting, 142-149.

Ozumba, V. C. (2013). Impact of Insurance on Economic Growth In Nigeria. International Journal of Business and Management Invention, 19-31.

Umoren, N. J., \& Emem, M. J. (2016). Relative Contributions of the Insurance Industry to the Growth of the Nigerian Economy. International Journal of Emerging Research in Management \&Technology, 189-198.

Yinusa , O., \& Akinlo, T. (2013). Insurance development and economic growth in Nigeria, 1986-2010. Journal of Economics and International Finance, 218-224. 